\title{
THE CONCEPT OF AIRPORT OPERATION IN GDYNIA IN THE CONTEXT OF OPTIMIZATION OF SOLUTIONS FOR THE DEVELOPMENT OF AIR TRANSPORT IN THE POMERANIA REGION
}

\begin{abstract}
The article covers issues related to the availability and use of terrestrial ground infrastructure existing in the Tri-City area. Its main purpose is to present and recommend functional solutions that will enable optimal development of air transport in the Pomeranian region. Such a solution would be a described model based on two complementary airports of public use. Thanks to this, the demand for air traffic from commercial users as well as non-commercial users in the area of general aviation will be better met. One of the basic assumptions for the presented solution is the complementarity, and effective use of existing resources and capabilities now and in the future. The whole is based on historical and current quantitative data and forecasts for the development of air traffic.

Keywords: airport, airport management, air traffic, air transport, busines aviation, complementary airports, flight training, general aviation, infrastructure, private flights, regional development
\end{abstract}

\section{Introduction}

Airports are a basic infrastructure element enabling the functioning of air transport. They are an important element of regional development, and their existence is an important factor determining the communication accessibility of the region ${ }^{1}$.

Due to the availability of airports for users, we divide them into public and exclusive use. An airport for public use is an airport open to all aircraft on the dates

1 S. Chakuu, P. Kozłowski, M. Nędza, Podstawy transportu lotniczego, Konsorcjum Akademickie, KrakówRzeszów-Zamość 2012, p. 113. 
and times agreed by the airport manager and made available to the public, whereas the exclusive use airport is used by the airport manager, users named in the airport's registration documentation and with the airport manager's consent - other users. Due to the role in the country's development policy, local (communal, district) and supralocal (regional, domestic) airports are distinguished ${ }^{2}$.

There are real barriers to terrestrial air transport infrastructure (airports), which significantly hinder and limit the possibility of their creation and development. These are permanent barriers resulting from the limited natural resources, i.e. environmental protection and spatial development, including existing infrastructure for other modes of transport. The most important temporary barriers include the economic barrier, and other important factors are technical, technological and organizational factors ${ }^{3}$.

Facilities such as airports are characterized by large local land use. They occupy a large area, and also force the need to meet certain conditions in their surroundings. This usually leads to restrictions in spatial planning and is associated with a significant impact on the environment. It is more justifiable to look for solutions that rely on the optimal use of existing infrastructure resources. This applies to both commercial transport and other aviation activities - from the broadly understood general aviation. Such an existing resource for the Pomeranian region is the military airport of Oksywie, where activities were carried out for years to start civil activities there.

The very idea of a system approach to the use of aviation infrastructure facilities in the region is not new. Already in 2006, professor A. Rucinski presented the article at "the new quality of transport and logistics after accession to the European Union" Conference, in which he described the concept of construction and operation of the Pomeranian Air Transport Area ${ }^{4}$. In 2010, a research report was prepared for the Ministry of Science and Higher Education - "Strategy for the construction and development of the Pomeranian Air Transport Area", where important premises indicating the purposefulness of such solutions were presented. This study put emphasis on the effective use of the existing ground infrastructure of the Gdansk Airport, and also indicated the potential of two military airports - in Pruszcz Gdański and Gdynia, which were to be designed to form the Node concerned. An important argument for the described solutions was the limitations in the possibility of expanding the Gdansk Airport and the expected use of the Gdansk airport's adaptation reserves with the number of 3.5-5 million passengers during the year ${ }^{5}$. At that time (2010) organizational work on the adaptation of the military airport in Gdynia to civilian operations was in an advanced phase, while in the case of the airport in Pruszcz Gdański, no action was taken in this direction.

The Act of July 3, 2002 Air law (Journal of Laws of 2011, No. 240, item 1429).

3 K. Wojewódzka-Król, R. Rolbiecki, Infrastruktura transportu, University of Gdańsk Publisher, Gdańsk 2010, p. 39.

4 A. Ruciński, The concept of construction and operation of the Pomeranian Airports, Conference of Departments of Transport and Logistics of the University of Gdańsk: "The new quality of Polish transport and logistics after the accession to the Union European Union", Sopot 2006.

5 A. Ruciński, D. Rucińska, D. Tłoczyński, P. Gałka, Strategia budowy i rozwoju Pomorskiego Węzła Lotniczego - Raport z badań dla MNiSW, University of Gdańsk, Sopot 2010, p. 91-92. 


\section{General characteristics of air transport in Poland}

Since Poland's accession to the European Union, air transport has been one of the fastest growing branches of transport. This can be seen perfectly on the example of Polish airports, which in 2004 served a total of 8.84 million passengers, and in 2017 this number increased to 40 million $^{6}$. During this period, the role of regional airports significantly increased, whose share in the total passenger transport market increased from $31 \%$ to $61 \%$.

Commercial air transport in Poland is based today (2018) on the network of existing 15 airports. Four of them are relatively new objects, commissioned for use in 2012-2016 (Modlin and Lublin 2012, Radom 2014, Olsztyn-Szymany 2016). The only Polish airport servicing over 10 million passengers annually is the Warsaw Chopin Airport (15.75 million in 2017). It is also the only port in Poland which, according to the classification used by the European Commission, falls into A category (large community airports, over 10 million passengers per year). In B category (domestic airports, 5-10 million) in 2017, the Kraków Airport was located with the result of 5.83 million passengers. Five more airports (Gdańsk, Katowice, Modlin, Wrocław, Poznań) were classified in C category (large regional airports, 1-5 million), and the remaining ones were in $\mathrm{D}$ category (small regional airports, less than 1 million passengers per year) ${ }^{8}$.

The growth rate of transport has been at a very high level for years and is much higher than in other Western European countries. In the period from 2010 to 2016, the Polish market increased by over $75 \%$. At the same time, transport in the EU-28 countries increased by $25 \%$, and in neighboring Germany "only" by $20 \%{ }^{9}$. Such large values and differences in relation to "old Europe" result to a large extent from the fact that Poland has been a relatively new, young and growing market since joining the European Union. However, the continuing trends show its attractiveness and still significant development potential. The current forecast of air traffic expects to reach a level of nearly 95 million passengers in Poland by $2035^{10}$.

The structure of transport (due to the carrier's business model) includes: network, low-cost and charter carriers. However, the main driving force for air traffic in Poland is LCC, in particular the two largest ones: Ryanair and Wizzair, which together account for over $50 \%$ of the market share. This is especially evident in the regional airports, where LCC flights represent the vast majority of operations performed.

In addition to typical air transport, the air traffic known as General Aviation (GA) is also developing significantly. The International Civil Aviation Organization (ICAO) defines general aviation operations as "operations involving the use of aircraft, other than those performed as commercial air transport or as part of air

\footnotetext{
6 http://www.pasazer.com/news/37419/raport,ponad,40,mln,pasazerow,w,polsce,w,2017,r.html (access: 15.02.2018).

7 Civil Aviation Authority, http://ulc.gov.pl/pl/regulacja-rynku/statystyki-i-analizy-rynku-transportu-lotniczego (access: 15.02.2018).

8 Announcement of the European Commission, 2005/C 312/01, (Dz.U.UE.C.05.312.1).

9 Based on the EUROSTAT data.

${ }_{10}$ Civil Aviation Authority.
} 
services"11. This means that General Aviation (GA) covers a wide range of air operations (private and commercial), from paragliding flights to jet aircraft flights. This is the aviation sector, which in recent years in Poland is characterized by very dynamic growth. This is proved, among others, by statistics of the Polish Air Navigation Services Agency, presented in the chart.

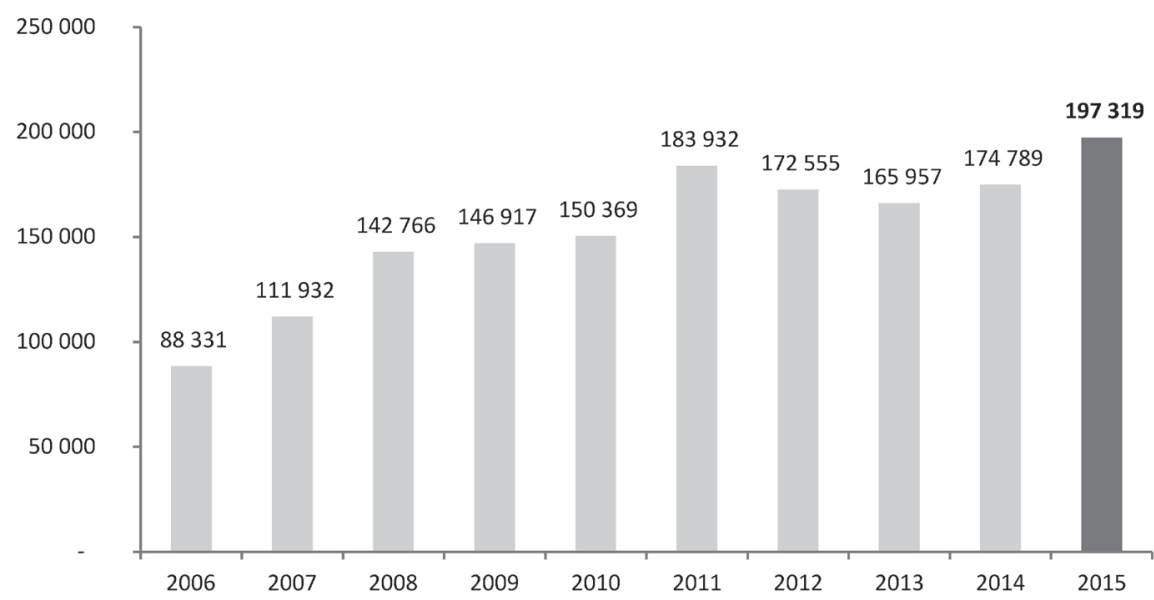

Figure 1. Number of general aviation operations in Poland in 2006-2015 (numbers of connections made with Flight Information Service)

Source: own elaboration based on data of the Polish Air Navigation Services Agency, https://dlapilota. pl/wiadomosci/dlapilota/jest-niezle-widac-ozywienie-w-lotnictwie-ogolnym (access: 15.02.2018)

The actual number of GA air operations in Poland is incomparably greater, as the values presented in the chart refer only to the "number of connections made with the Flight Information Service" and do not take into account the vast majority of flights performed only in areas/zones of airports (e.g. flight training). In addition, it is necessary to emphasize the constantly growing number of private aircraft held by natural persons in Poland. This number according to the data of the Civil Aviation Office, increased in $2010-2016$ by $42 \%^{12}$. This also indicates a dynamically growing demand for infrastructure and services covering the general aviation sector.

While in the case of typical airports, we can talk about meeting European standards (all Polish airports, obligated under Article 6 (1) of the EU Commission Regulation No. 139/2014 of 12 February 2014 to convert national certificates into European Union certificates, successfully passed the conversion process) $)^{13}$, while in the case of others - smaller airports, differences in relation to Western European countries remain significant. The number of GA dedicated facilities, especially those that have a paved runway, navigational aids, or adequate infrastructure, is much lower in Poland than in other countries. Particularly noticeable is the lack of generally accessible airports (of public use). The smaller airports and airstrips existing

\footnotetext{
11 Annex No. 6 to the Convention on International Civil Aviation, ICAO, Montreal 2008.

12 Register of Civil Air Vessels of the Civil Aviation Office.

${ }^{13}$ Civil Aviation Authority, http://ulc.gov.pl/pl/247-aktualnosci/4322-zakonczenie-procesu-konwersji-certyfikatow-krajowych (access: 17.02.2018).
} 
in Poland, with a few exceptions, usually operate in a model where the operator also carries out activity appropriate for users, which in practice significantly limits the possibility of locating independent entities that run a competitive activity.

\section{Organization of air transport in the region}

Air transport in the Pomeranian region is based on the Lech Walesa Airport in Gdansk. This is the third airport in Poland in terms of the number of passengers served. In 2010-2015, investments were made here involving significant expansion of existing infrastructure. They were given, among others, a completely new, second terminal for use, a parallel taxiway was built and new parking spaces for airplanes. The renovation of the runway and the lighting system was also carried out, which translated into raising the category of the airport from CAT I to CAT II. The second category (CAT II) according to the standards of the International Civil Aviation Organization (ICAO) enables performing air operations in atmospheric conditions, when the minimum horizontal visibility along the runway (RVR) is $300 \mathrm{~m}$, and the cloud base is at a height of 30 meters (for CAT I these are 550/60 respectively). All this meant that the operational capacity and airport capacity increased several times. In addition, the accompanying infrastructure was also expanded: access roads and parking lots, and the Pomeranian Metropolitan Railway were opened, thanks to which the airport gained a direct rail connection to the city center.

In 2017, a record number of 4.61 million passengers were served in Gdansk Airport, which is more than a 10 -fold increase over the last 13 years. The airport has about $12 \%$ share in the domestic passenger transport market and about $4.5 \%$ in air freight transport. The capacity declared at present (2018) is 7 million passengers a year. Already, however, new investments are planned, the aim of which is to increase it to around 9 million $^{14}$.

Gdansk Airport is the only airport in the region where commercial air transport takes place. Both traditional and low-cost carriers operate here. In addition to commercial traffic, General Aviation flights are also taking place, but, in principle, large communication airports are not the optimal place for this type of operation. This is due to formal requirements, the amount of fees or difficulties and limitations resulting from the specificity and level of commercial air traffic, which is the basic area of activity at this type of airports. The number of operations in Gdansk Airport referred to as "non-commercial" is about a little over 2000 (data for 2015 - the last year for which statistics are available). This represents an increase of $65 \%$ compared to 2004 (1254 operations). Increasing the number of commercial operations in the same period from 16287 to 38189 , as well as a 10-fold increase in the number of passengers in 2014-2017 is confirmed by the commercial profile of the Gdansk Airport ${ }^{15}$.

\footnotetext{
${ }_{14}$ Aviation market, http://www.rynek-lotniczy.pl/wiadomosci/gdansk-w-ciagu-dwoch-lat-rozpocznie-sie-budowa-pirsu-3052.html (access: 22.02.2018).

15 Data from the website of PL Gdańsk, http://www.airport.gdansk.pl/airport/statistic/ (access: 15.02.2018).
} 
Other objects in the region where civil aviation activity is carried out are ${ }^{16}$ :

- Pruszcz Gdański (military airport - aviation activity of the Gdansk Aero Club association, lack of the actual possibility of locating aviation entities other than the Gdansk Aero Club);

- Jastarnia (seasonal, grassy runway);

- Elbląg (Elbląg Aero Club, grassy runway);

- Korne (gliding, paragliding, airplanes in a very limited range, grassy runway);

- Borsk (post-military airport with an artificial runway, currently mainly paragliding);

- Słupsk (Krępa - Słupsk Aero Club, grassy runway);

- Grudziądz (Lisie Kąty - Aero Club, grassy runway);

- Watorowo (FTO Adriana Aviation, commercial training center - airplanes, grassy runway).

None of these facilities is an airport of public use and except Jastarnia, which in the summer mainly serves as a landing site, on each of these landing sites the manager (operator) also conducts activities typical for the user (training, other flights, service, hangar, refueling on own use, etc.)

Founded in 1929, the Gdansk Aero Club association is one of the oldest aviation organizations in Poland. Currently, it is also the largest organization in the field of general aviation in Pomerania. Aero Club conducts airplane, glider, parachute, microlight and ballooning as well as modeling activities. The main profile of the activity is air training - including airplane training. Since 1974, the Aeroclub has been operating at an active military airport belonging to the $49^{\text {th }}$ Combat Helicopter Base in Pruszcz Gdanski, where it has ownership of a small area with its headquarters located there. A certain advantage of the Pruszcz Gdanski airport is a paved runway. However, from its original - a total length of $2.5 \mathrm{~km}$, only a segment of $1162 \mathrm{~m}$ is operatively maintained ${ }^{17}$. The use of the runway for civil operations takes place with the consent of the military side and due to the status of the active state airport, it is practically limited to flights as part of the Aeroclub's activity. According to our knowledge, no action has been taken to change this status, and the airport in Pruszcz Gdański is to remain a military facility.

Aircraft training, in the basic scope, is also conducted at the Aero Clubs in Słupsk, Elbląg and in Grudziądz. Due to the fact that the mentioned Aeroclubs have landings with grass surface, their activity is limited to a large extent to the spring - autumn period. The place where there is a relatively large number of flights seasonally is also a landing ground in Jastarnia. The attractive location on the Hel Peninsula causes a large number of external users to use it during the summer. However, its dimensions and location, as well as the lack of additional infrastructure, significantly limit operational capabilities. In practice, this means that only small tourist airplanes, adapted to operate from unpaved surfaces, land here.

The closest - typically commercial air center is FTO Adriana Aviation. The resort is located about $100 \mathrm{~km}$ from the Tri-City, in Watorowo. In Adriana Aviation, comprehensive theoretical flight training (including the level of ATPL - Airline Transport Pilot License) has been conducted for many years, practical and simulation to the full

16 AIP Poland, http://ais.pansa.pl/aip/ (access: 22.02.2018).

17 Ibidem. 
extent possible for the GA training organization. It is a private resort, with its own grassy landing ground, enabling night flights (lighting), administration buildings, technical facilities, a hangar and its own hotel base. All this makes Adriana Aviation a significant entity on the national scale, and in the absence of the ability to get a license closer - there are also a lot of people from the Tri-City area.

\section{Gdynia Airport - as an existing resource}

Oksywie military airport is located about $7 \mathrm{~km}$ north of the center of Gdynia. It is used by the $43^{\text {rd }}$ Maritime Naval Air Base. Every day, M-28 "Bryza" planes and helicopters operate here. Formal activities aimed at transforming part of the airport for civilian needs started already in 2005, when with the participation of the Minister of National Defense, representatives of local governments signed a letter of intent regarding the adaptation and expansion of the airport for the needs of a civil airport. According to this agreement, the management of the future Gdynia-Kosakowo Airport was to be entrusted to the Gdansk Airport. However, this idea collapsed and in 2007 the local government authorities of Gdynia and Kosakowo established Gdynia Kosakowo Airport. In December 2010, permission was received from the Ministry of Transport that it was this company that carried out the investment aimed at the creation of a civilian airport, and then managed the launched airport. In accordance with the plans of the shareholders and the management board of the Company, a civil airport was to be created on the base of the military airport of Gdynia-Oksywie, which supplements the air transport services offered at the Gdansk Airport.

The construction works related to the adaptation of the military airfield to civil aviation requirements actually began in 2011. As a result, there were created an access road to the airport, a fence, an administrative and operational building, terminal (not completed), parking lots, fuel base, apron dedicated to GA, as well as a system of illuminating navigation aids.

In February 2014, the European Commission issued a decision indicating that the investment expenditures made by partners (the Municipality of Gdynia and the Commune of Kosakowo) constitute prohibited public aid and ordered their return. As a result, the company carrying out the investment in bankruptcy (from May 2014) was put into operation and the project of building the airport was completely suspended. The municipality appealed against this decision to the General Court of the European Union in Luxembourg and in November $17^{\text {th }}, 2017$ it issued a decision in which it cancelled the decision of the European Commission. In January 2018, the Commission appealed against this decision to the European Court of Justice. The city of Gdynia, however, has already been negotiating with the Commission much earlier, which, despite the ongoing proceedings by the European authorities, are still ongoing. Their goal is to open the airport and launch civilian operations in Gdynia ${ }^{18}$.

18 Based on internal materials of the Gdynia City Hall. 
Currently (2018), in the part of the airport, which has been transferred to civilian activity, objects already in existence are permanently maintained in order to prevent their degradation. It should be assumed that, apart from the terminal itself, which has not been completed, the airport has a ready infrastructure to start operations. These are:

- runway with dimensions of $2500 \times 60 \mathrm{~m}$;

- taxiway system;

- apron (aircraft parking) with dimensions of $250 \times 40 \mathrm{~m}$;

- additional hardened surfaces (to be used for parking the aircraft);

- fuel base;

- a system of light navigation aids;

- buildings with parking lots and access roads.

The runway, taxiways and aprons form the so-called "Movement Area" (MA). The parameters of individual elements of the MA are fully sufficient for operating the GA operations at the airport. The runway itself meets much higher parameters also suitable for typical commercial transport operations, but the size of the existing elements (taxiways, apron) that currently allow the airport to obtain the ICAO standard corresponding to the reference code $4 \mathrm{~B}$. This translates in practice to the ability to operate aircraft with wingspan up to $24 \mathrm{~m}^{19}$. An important element of the existing infrastructure is a modern system of illuminating navigation aids. The airport also has significant field reserves, allowing the construction of facilities for homing and servicing aircraft. The favorable layout of the existing individual MA elements (taxiways, aprons) creates significant opportunities for creating solutions that are conducive to potential users.

In addition to the infrastructure resources mentioned, the Gdynia airport's determination to launch the airport, establishing at the ministerial level (transfer of real estate) and substantive arrangements (speech, instructions) setting out the rules for conducting civilian activities are an important argument for the presented concept. The regulations currently in force (amendment of the Aviation Law) allow the creation of public use airports in the limited certification formula. In relation to earlier regulations in this respect, it creates the possibility of a significant reduction of the costs of the very start-up and operation of the airport ${ }^{20}$. The land use agreement (State Treasury) and the lease of the airport property was concluded for the period up to 2040, but there are no reasons to assume that civil aviation activities at the airport could be terminated after this period ${ }^{21}$.

\section{The concept of functioning}

The presented concept assumes a functional model of air transport organization in the region based on two complementary airports, which on the one hand

19 Annex No. 14 to the Convention on International Civil Aviation, ICAO, Montreal 2009.

20 Regulation of the Minister of Transport, Construction and Maritime Economy of 18 June 2013 on technical and operational requirements in relation to public use airports for which a decision on limited certification was issued (Journal of Laws of 2013, item 799).

21 Based on internal materials of the Gdynia City Hall. 
is a continuation of assumptions from previous projects and studies (Pomeranian Aviation Junction), and on the other - adaptation of planned intentions to the current and predicted situation in the field of air traffic organization. Compared to the initial assumptions of the Pomeranian Aviation Junction, this study takes into account the changes that have taken place over the past years, i.e. in particular: the expansion and significant increase in capacity of the Gdansk Airport, the structure of transport in regional ports, and the level of implementation (currently suspended) project for the launch of the Gdynia airport. For the reasons given earlier in the concept, the airport in Pruszcz Gdański was not included, thus limiting the functional model presented to two airports.

The basic assumption for the presented concept - in relation to the functioning of the Gdynia airport, is to create optimal conditions for the development of air traffic, which in the operational scope has been defined as General Aviation, and in the commercial context - as non-commercial. Figure 2 presents a model, where the functional division of different types of aviation activities is schematically shown - in relation to the nature, capabilities and potential of individual airports. The main assumptions here are efficiency and complementarity, and the proportions shown in the figure should be treated conventionally at this stage. However, they are based on some objective and obvious dependencies.

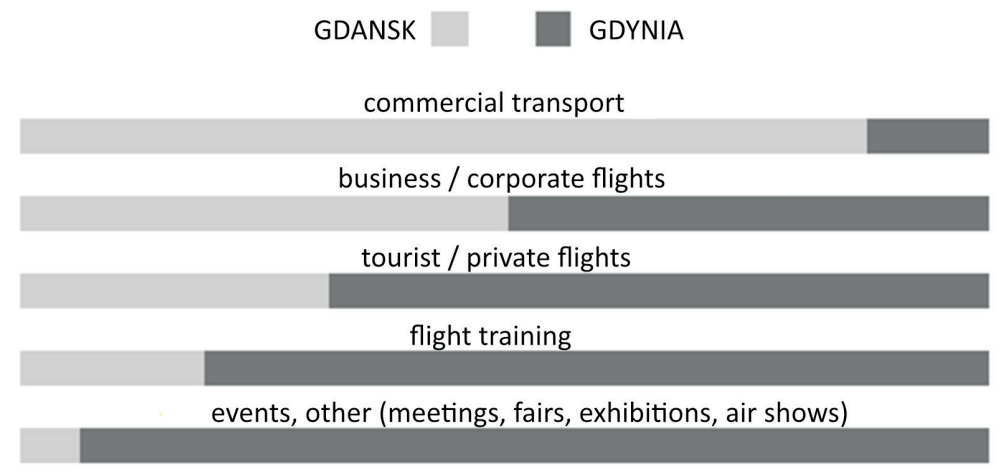

Figure 2. Functional model for air traffic organization in the region - two complementary airports

Source: own elaboration

The dynamically developing Gdansk Airport is already a place where it is difficult to conduct certain operations regarding general aviation - even due to the high volume of commercial traffic. This applies in particular to activities in the field of flight training, but also to tourist and private flights. These problems are not and will not be in Gdynia, where air traffic is limited almost exclusively to military aircraft operations belonging to the $43^{\text {rd }}$ Marine Aviation Base stationed here. Both the current and future-forecasted number of military flights does not constitute and will not be a problem for the anticipated civil activity. This has 
been repeatedly confirmed in the agreements and arrangements for the sharing of the airport already concluded with the military side ${ }^{22}$.

In the field of typical commercial transport, the role of the Gdansk Airport is obvious and indisputable. This is due to the actual possibilities, equipment and existing infrastructure intended for servicing this type of air traffic. Investments already completed and planned in the coming years are a response to the growing demand in the region. The operational parameters of the Gdansk airport, including the CAT II category (planned upgrade to CAT III), make it meet all the standards expected of a modern airport.

In the field, which was defined as business/corporate flights, a definite shift towards the other object is already visible. Nevertheless, in this respect, the Gdansk airport is also fully functional. This kind of activity is and can still be successfully carried out here. However, the Gdynia airport also creates great opportunities in this area, both in the context of the operations themselves as well as field resources for homing and technical service.

In the area of tourist/private flights, the potential advantage of Gdynia is already very clear. The specificity of the aircraft used for this type of aviation activity, as well as the very nature of the flights, make the "less formal" airports much more preferred. An important factor is also airport charges, which are usually much higher in typical airports than at other airports

Flight training is a type of activity for which the objective difficulties in the Gdansk port are most noticeable. The confirmation is that such flights practically do not take place there, and if they are, they are rather incidental. For the same reasons, no pilot training center is operating at the Gdansk airport. 4.6 million passengers in 2017 and the planned achievement of the level of 5 million in 2018 make the number of commercial operations significantly interfere with possible training, and the specificity of school flights is, among others, on the fact that they are characterized by high frequency of takeoffs and landings performed in a short time.

Commercial activities of PL Gdansk makes it virtually impossible to organize any events, air shows and other open/mass events. Such activities can be successfully implemented at the airport in Gdynia. Although it has not yet been launched as a civilian one, in recent years such spectacular events as the international Red Bull Air Race (2014) took place here, and in 2017 there were air shows that are planned again in 2018. Attractive location favours such projects that are very popular and undoubtedly contribute to the promotion of the region.

Operational and organizational possibilities of two attractively located facilities, one of which (PL Gdansk) is a large, well-functioning airport, and in the case of the other (Gdynia) activities are undertaken to launch the public use airport operation in the limited certification formula, indicate high potential in creating solutions that will respond to the challenges of increasing air traffic. The second airport of public use - dedicated to the GA activity, is an important complement to the existing offer in the field of terrestrial infrastructure for the operation and comprehensive development of aviation activities. 
The size and operational parameters of the Gdynia airport, including, in particular, the runway, the layout of other elements of the terrestrial traffic field, as well as the already completed investments also indicate the possibility of commercial operations in the future. However, the possible undertaking of activities aiming at this type of activity should depend on the actual needs in satisfying the demand for air transport in the region, and in particular on the possibility and possible need to support and supplement the transports performed in PL Gdansk. Despite the assumptions currently adopted, i.e. limitations in Gdynia to only the General Aviation segment, it cannot be ruled out that in the future - especially in the event of a capacity shortage at the Gdansk Airport, the infrastructure of the Gdynia airport may also offer its operational capabilities for air transport. In this context, besides the typical "capacity", other aspects are also worth considering, including environmental, spatial and communication. At this stage, however, it is assumed that this would be possible only in the event of a possible agreement in this matter with Gdansk Airport and when it is considered economically and commercially reasonable.

\section{Expected benefits}

The operation of two complementary airports in the Tri-City will create unique opportunities in the country for the operation and development of air transport, including the wider general aviation segment. It will complement the available infrastructure offer regarding the public use airports with solutions enabling a significant increase in the number of individual users as well as companies from the General Aviation area. It should be assumed that in the case of the emergence of a new, dedicated to the GA facility, the interest in private aviation tourism will increase and the economic potential of the region will be a factor conducive to the development of business aviation.

An extremely important element of the concept is the introduction of solutions enabling development in the field of air training. The signals coming from the market confirm a lot of interest from many entities that are ready to locate their activities in this area. An additional argument is the possibility of combining airport operations with practical training of personnel for civil aviation services. At present, there are three academic centers in Poland (Rzeszów University of Technology, State Higher Vocational School in Chełm and Higher School of Air Forces in Dęblin), in which systematic training in the field of pilotage takes place. In addition, there are many commercial centers where you can get the necessary qualifications to practice the pilot profession. The dynamically developing market creates an increase in the demand for airline personnel. The business plans and the possibilities of using the Gdynia airport are also perfectly suited to this trend.

Air training and training activities usually also influences the amount of private aircraft based in a given location. This in turn makes it necessary to provide adequate facilities and technical service. Also in the scope of providing external services (repairs, airworthiness management), the potential for the development of this type of activity is significant. 
An important argument is also the creation of an offer for safe and comfortable homing of aircraft. The possibility of permanent stationing is one of the basic factors influencing the quantitative and qualitative development of GA aviation. The location of the airport, the existing favourable arrangement of elements of the terrestrial traffic (taxiways, plane parking plates), as well as the assumed future functionality of the airport in Gdynia creates great opportunities in this area.

It should also be possible to conduct various activities around the air, i.e. to organize all kinds of events, meetings, shows, exhibitions, fairs, etc. All this makes the potential benefits of starting a civil activity at the Gdynia airport seem obvious and will undoubtedly contribute to the increase of the attractiveness of the entire region.

The growing demand for services dedicated to GA and the lack of a comprehensive, generally available infrastructure offer justify the reality of the concept for the Gdynia airport as an object dedicated to general aviation, which would be a natural complement to the Gdansk Airport. Open and accessible throughout the year, the airport with adequate terrestrial infrastructure, gives the opportunity to safely and effectively conduct a wide range of activities. All this creates conditions for the Tri-City to become an important center for the functioning and development of general aviation, not only in Poland, but also in Europe.

\section{Conclusions}

The functional model presented in the concept is based on the complementarity, here understood, as supplementation by the Gdynia airport with offers in the field of terrestrial ground infrastructure, which cannot be and is not complete. This will be ensured by the optimization of conditions for the development of air traffic and broadly understood around aviation activities. It is a solution that enables, above all, the development of all aviation activities from the General Aviation area. The dynamic development of aviation makes it the most appropriate to look for solutions that allow us to meet current and future demand, also from non-commercial air traffic participants. Effective use of the resources already possessed is most desirable here and the infrastructure created and existing at the airport in Gdynia should be used in accordance with its purpose.

Gdynia airport naturally fits in with the presented concept, where apart from the typically commercial aviation activity in the field of transport, the needs of other users were also taken into account. The attractive location of both the Tri-City and the airport in Gdynia means that the demand for air traffic is significant here and will continue to grow. Striving to create a model that would include two complementary airports seems to be the right path, leading to the optimization of solutions for the development of air transport in the Pomeranian region.

\section{References}

AIP Poland, http://ais.pansa.pl/aip/ (access: 22.02.2018).

Annex No. 6 to the Convention on International Civil Aviation, ICAO, Montreal 2008. 
Annex No. 14 to the Convention on International Civil Aviation, ICAO, Montreal 2009.

Aviation market, http://www.rynek-lotniczy.pl/wiadomosci/gdansk-w-ciagu-dwoch-lat-rozpocznie-sie-budowa-pirsu-3052.html (access: 22.02.2018).

Chakuu S., Kozłowski P., Nędza M., Podstawy transportu lotniczego, Academic Consortium, Kraków-Rzeszów-Zamość 2012.

Civil Aviation Authority, http://ulc.gov.pl/pl/regulacja-rynku/statystyki-i-analizy-rynku-transportu-lotniczego (access: 15.02.2018).

European Commission Communication 2005/C 312/01 (OJ.UE.C.05.312.1).

EUROSTAT, ec.ueropa.eu/eurostat (access: 15.02.2018).

https://dlapilota.pl/wiadomosci/dlapilota/jest-niezle-widac-ozywienie-w-lotnictwie-ogolnym (access: 15.02.2018).

http://www.pasazer.com/ (access: 15.02.2018).

Internal materials of the Gdynia City Hall.

Lech Walesa Airport in Gdańsk, http://www.airport.gdansk.pl/ (access: 15.02.2018).

Regulation of the Minister of Transport, Construction and Maritime Economy of 18 June 2013 on technical and operational requirements in relation to public use airports for which a decision on limited certification was issued (Journal of Laws of 2013, item 799).

Ruciński A., Koncepcja budowy i funkcjonowania Pomorskiego Węzła Lotniczego [in:] Nowa jakość polskiego transportu i logistyki po akcesji do Unii Europejskiej, eds. D. Rucińska, E. Adamowicz, FRUG, Gdańsk 2006.

Ruciński A., Rucińska D., Tłoczyński D., Gałka P., Strategia budowy i rozwoju Pomorskiego Węzła Lotniczego - Raport z badań dla MNiSW, University of Gdańsk, Sopot 2010.

Wojewódzka-Król K., Rolbiecki R., Infrastruktura transportu, University of Gdańsk Publisher, Gdańsk 2010.

The Act of July 3, 2002 Air law (Journal of Laws of 2011, No. 240, item 1429).

\section{Corresponding author}

Marcin Żurawiecki can be contacted at: marcinzurawiecki1970@gmail.com 